\title{
Łukasz Jończyk
}

Zespół Szkół im. Orląt Lwowskich w Tychach

Zakładu Doskonalenia Zawodowego w Katowicach

lukaszjon@gmail.com

iD https://orcid.org/0000-0002-8846-2706

\section{Propagandowe wykorzystanie w czasach panowania Augusta odzyskania znaków legionowych utraconych pod Carrhae}

\begin{abstract}
Abstrakt: Marek Licyniusz Krassus w trakcie wyprawy przeciwko imperium Partów poniósł klęskę pod Carrhae, w wyniku której poległ. Wrogowie przejęli wtedy znaki legionowe pokonanej armii. Dążenie do ich odzyskania określiło cele rzymskiej polityki na Wschodzie w następnych latach. Stało się również priorytetem rzymskiej propagandy w czasach Augusta.
\end{abstract}

Słowa kluczowe: starożytny Rzym, Krassus, August, poezja, propaganda

$\mathrm{W}$ artykule podjęto próbę określenia znaczenia, jakie nadawano dążeniom do odzyskania signa militaria utraconych przez legiony Marka Licyniusza Krassusa (M. Licinius Crassus) pod Carrhae w 53 roku p.n.e. Ustalono również przyczyny, z powodu których kwestii tej nadano tak wielką rangę. Do realizacji tych celów badawczych wykorzystano różnorodne źródła, spośród których wyróżnić trzeba Res Gestae autorstwa pierwszego cesarza ${ }^{1}$. Innym rodzajem źródeł pisanych, dobrze obrazującym ówczesną propagandę, a także wyrażającym nastroje panujące wówczas w pewnych kręgach społeczeństwa, jest poezja. Do twórców epoki Augusta w szczególny sposób nawiązujących do kwestii łączących się z badanym tematem należeli: Horacy (Q. Horatius Flaccus), Owidiusz (P. Ovidius Naso) oraz Propercjusz

${ }^{1}$ Zob. np. w tym kontekście: RG 27, 29; Vell. Pat. II, 91, 94; Suet., Aug. 21; Tib. 9; Cass. Dio LIV, 8,$4 ; 9,4-5$. W przypadku tekstu autorstwa Augusta ważny jest wysoce propagandowy charakter tego utworu. Na tę jego cechę uwagę zwrócił m.in. Z. YAvetz (The Res Gestae and Augustus' Public Image. W: Caesar Augustus Seven Aspects. Eds. F. Millar, E. Segal. Oxford 1984, s. 1-36). 
(Sex. Propertius) $)^{2}$. Przeprowadzenie badań nad omawianą problematyką umożliwiły również zabytki materialne, zwłaszcza te, które z założenia były nośnikiem propagandy państwowej, czyli monety, budowle oraz inne dzieła sztuki ${ }^{3}$. Na podstawie analizy treści zamieszczonych w wymienionych materiałach źródłowych można wysnuć wnioski o znaczeniu, jakie problemy omawiane w artykule miały dla rzymskich władz. Dla odpowiedniego zinterpretowania informacji zawartych w źródłach istotne były również dane faktograficzne, o których można przeczytać w dziełach m.in. Wellejusza Paterkulusa, Swetoniusza oraz Kasjusza Diona.

Signa militaria utożsamiano z bogami prowadzącymi Rzymian do bitwy ${ }^{4}$. Były to m.in. wizerunki zwierząt, symbole kohort, vexillum, imago imperatoris oraz główny sztandar legionu, czyli orzeł ${ }^{5}$. Znaki legionowe - jako symbol obecności bóstw - otaczano czcią religijną ${ }^{6}$. Jak zauważył Mieczysław S. Popławski, utrata signa militaria była nie tylko grzechem i hańbą, lecz także „wielkim nieszczęściem”, ponieważ powodowała zaprzestanie współbytowania z tymi bogami, ich opieką i pomocą ${ }^{7}$. Odzyskanie znaków przywracało współżycie z bóstwami. Dlatego oprócz politycznego ważny był również sakralny aspekt dążeń Augusta, które miały doprowadzić do rozwiązania kwestii przejętych przez Partów signa.

Pierwszą próbę pomszczenia klęski poniesionej przez Krassusa pod Carrhae i utraconych wtedy znaków legionowych podjął już Cezar (C. Iulius Caesar), planując w 44 roku p.n.e. wyprawę na Wschód ${ }^{8}$. Następnie w 36 roku p.n.e. przeciwko

2 Wzmianki dotyczące odzyskania signa Horacy zamieścił w Pieśniach (Carmina) oraz Listach (Epistulae), Propercjusz w Elegiach (Elegiae), a Owidiusz w Sztuce kochania (Ars amatoria), Kalendarzu poetyckim (Fasti) oraz Żalach (Tristia).

${ }^{3}$ Wpływ propagandowych treści zawartych w dziełach sztuki na odbiorców omawia T. HöLscher (Sztuka rzymska: język obrazowy jako system semantyczny. Tłum. L. Olszewski. Poznań 2011). Analizy wielu zabytków z czasów Augusta podjęli się P. ZANker (The Power of Images in the Age of Augustus. Trans. A. Saphiro. Ann Arbor 1990) i J.A. Ostrowski (Starożytny Rzym. Polityka i sztuka. Warszawa-Kraków 1999, s. 181-238).

${ }^{4}$ M.S. PopŁAwski: Bellum Romanum. Sakralność wojny i prawa rzymskiego. Lublin 2011, s. 32; H.L. KRYśKIEW ICZ: Signa recepta w starożytnym Rzymie 20 roku przed Chrystusem. Kontekst polityczny oraz ideologiczny sukcesu. Szczecin 2016, s. 18.

5 Veg. II, 13; L. Keppie: The Making of the Roman Army. From Republic to Empire. London 2005, s. 46; P. Southern: The Roman Army. A Social and Institutional History. Santa Barbara-DenverOxford 2006, s. 95; P. CAgniart: The Late Republican Army (146-30 BC). W: A Companion to the Roman Army. Ed. P. Erdkamp. Malden-Oxford-Carlton 2007, s. 87; O. Stoll: The Religions of the Armies. W: A Companion to the Roman..., s. 455; M.S. PopŁAwski: Bellum Romanum..., s. 40; H.L. KRYśkiewicz: Signa recepta..., s. 18-22.

6 P. Southern: The Roman Army..., s. 150, 162; M.S. Pop£Awski: Bellum Romanum..., s. 40—41, 66-69; H.L. KRYśKiEWiCz: Signa recepta..., s. 33-35.

7 M.S. PopŁAwski: Bellum Romanum..., s. 42.

8 Plut., Caes. 58; J.W. Rich: Augustus's Parthian Honours, the Temple of Mars Ultor and the Arch in the Forum Romanum. „Papers of the British School at Rome” 1998, 66, s. 72; A. KAmm: Julius Caesar. A Life. London-New York 2006, s. 141; A.D.H. BIvAR: The Political History of Iran under the 
Partom wyruszył Marek Antoniusz (M. Antonius). Jednak jego ekspedycja zakończyła się ponowną klęską i stratą kolejnych signa ${ }^{9}$. W konsekwencji aż do objęcia władzy w imperium rzymskim przez Augusta w styczniu 27 roku p.n.e. sprawa znaków legionowych armii Krassusa pozostała nierozwiązana.

Po przejęciu rządów princeps początkowo skupił się głównie na ugruntowaniu i umocnieniu swej pozycji w państwie, m.in. poprzez kumulowanie uprawnień przysługujących najważniejszym urzędnikom ${ }^{10}$. Natomiast w imperium partyjskim po objęciu tronu przez Phraatesa IV (ok. 37 roku p.n.e.) trwały walki dynastyczne, co osłabiało je w stosunku do Rzymu ${ }^{11}$. W takich okolicznościach oba kraje nie podjęły względem siebie działań. Sytuacja zmieniła się w 23 roku p.n.e., gdy do wschodnich prowincji imperium wysłano Marka Agryppę (M. Agrippa) ${ }^{12}$. Zadaniem tego

Arsacids. W: The Cambridge History of Iran. Vol. 3.1: The Seleucid, Parthian and Sasanian Periods. Ed. E. Yarshater. Cambridge 2006, s. 56; E. Rawson: Caesar: Civil War and Dictatorship. W: Cambridge Ancient History. Vol. 9: The Last Age of Roman Republic, 146-43 B.C. Eds. J.A. CrooK, A. Lintott, E. Rawson. Cambridge 2008, s. 466; G. Traina: Imperial Views on the Battle of Carrhae. W: War in Words. Transformations of War from Antiquity to Clausewitz. Eds. M. FormIsano, H. Böнme. Berlin-New York 2011, s. 212; M. MiLCZAnowsкi: W cieniu boskiego Juliusza. Imię Cezara w propagandzie u schyłku Republiki. Kraków 2013, s. 95; P. EDwell: The Euphrates as a Boundary between Rome and Parthia in the Late Republic and Early Empire. „Antichthon” 2013, 47, s. 199; H.L. KRYśKiewicz: Signa recepta..., s. 69-73. O zemście w kontekście wojen prowadzonych przez Rzymian i ich polityki wobec państw i plemion ościennych zob. P. MAdejSki: Pomiędzy robur animi a ritus barbarus: zemsta w życiu społecznym republikańskiego Rzymu. Lublin 2018, s. $153-180$.

9 Vell. Pat. II, 82; Liv. CXXX; Plut., Ant. 38-50; Flor. II, 20; Cass. Dio XLIX, 25; E.G. HuZAR: Mark Anthony. A Biography. Minneapolis 1979, s. 175-180; J. Wolski: Rzymska polityka na Wschodzie. Imperializm rzymski w konflikcie z imperializmem irańskim. W: Starożytny Rzym we wspótczesnych badaniach. Państwo, społeczeństwo, gospodarka. Liber in memoriam Lodovici Piotrowicz. Red. J. Wolski, T. Kotula, A. Kunisz. Kraków 1994, s. 91-92; J.W. Rich: Augustus's Parthian honours..., s. 72; G.A. Koshelenko, V.N. Pilipko: Parthia. W: History of Civilizations of Central Asi. Vol. 2: The Development of Sedentary and Nomadic Civilizations: 700 B.C. to A.D. 250. Eds. J. Harmatta, B.N. Puri, G.F. Etemadi. Paris 1996, s. 134; A.D.H. Bivar: The Political History of Iran... s. 58-66; Ch. Pelling: The Triumviral Period. W: Cambridge Ancient History. Vol. 10: The Augustan Empire, 43 B.C.-A.D. 69. Eds. A.K. Bowman, E. Champlin, A. Lintott. Cambridge 2008 (dalej: CAH 10), s. 31-34; G. Traina: Imperial Views..., s. 212; M. Milczanowski: W cieniu boskiego Juliusza..., s. 95-97; T. BRYCE: Ancient Syria. A Three Thousand Year History. New York 2014, s. 229-231; H.L. Kr yś́xiewicz: Signa recepta..., s. 73-77. Znaki legionowe armii Antoniusza zostały najprawdopodobniej odzyskane w 20 roku p.n.e. razem z signa legionów Krassusa.

10 Między innymi: RG 8, 17-18, 34; P. Southern: Oktawian August. Tłum. D. KozińsKa. Warszawa 2003, s. 161-167; R. Syme: Rewolucja rzymska. Tłum. A. BAzıór. Poznań 2009, s. 310-317; J.A. Crook: Political History, 30 B.C. to A.D. 14. W: CAH 10, s. 75-79.

${ }^{11}$ J. Wolski: Rzymska polityka na Wschodzie..., s. 92; A.D.H. Bivar: The Political History of Iran..., s. 58, 65-66; H.L. KRyśkiewiCz: Signa recepta..., s. 74, 79-89.

12 Vell. Pat. II, 93; Jos., Ant. XV, X, 2; Cass. Dio LIII, 32; P. SAwiński: Specjalni wysłannicy cesarscy od Augusta do Tyberiusza. Studium nad początkami pryncypatu. Poznań 2005, s. 27-29, 77-79; H.L. KRYśKiewiCz: Signa recepta..., s. 89-91. 
wodza i przyjaciela princepsa było prawdopodobnie uporządkowanie tamtejszych spraw oraz przygotowanie wizyty Augusta na tych terenach ${ }^{13}$. Cesarz wyruszył na Wschód jesienią 22 roku p.n.e. ${ }^{14}$ Ostatecznie w 20 roku p.n.e. jego pasierb Tyberiusz (Ti. Claudius Nero) osadził na tronie Armenii przychylnego Rzymowi Tigranesa III ${ }^{15}$, natomiast August sfinalizował z Phraatesem IV układ, na mocy którego Rzymianom zwrócono znaki legionów Krassusa ${ }^{16}$. W Rzymie signa zostały ostatecznie umieszczone w świątyni Marsa Ultora (Mściciela) w 2 roku p.n.e. ${ }^{17}$

Do zemsty na Partach nawoływano więc już w ostatnim okresie istnienia Republiki. Chęć odwetu miała podstawy zarówno polityczne, prestiżowe, jak i sakralne. Wydaje się, że po zakończeniu wojen domowych w Rzymie musiały się pojawić wezwania do ponownych prób pomszczenia dawnej klęski.

Nawiązania do odzyskania signa zawarte w tekstach, na monetach i w dziełach sztuki zostały określone w artykule jako „propaganda”. Termin ten jest wieloznaczny, współcześni badacze podają wiele jego definicji ${ }^{18}$. Niektórzy, pomimo powszech-

13 Taką koncepcję wysuwa H.L. KRYśKIEwicz (Signa recepta..., s. 89-91), podobnie również konstatuje P. SAWIŃski (Specjalni wysłannicy..., s. 78-79) oraz J.W. RicH (Augustus's Parthian honours..., s. 72).

${ }^{14}$ A.A. BARrett: Livia First Lady of Imperial Rome. New Haeven-London 2002, s. 36; P. SouthERn: Oktawian..., s. 184; R. SeAger: Tiberius. Bodmin 2005, s. 14; R. Syme: Rewolucja rzymska..., s. 376; H.H. Scullard: From the Gracchi to Nero: A History of Rome 133 BC to AD 68. LondonNew York 2010, s. 182; H.L. Kryśkiewicz: Signa recepta..., s. 91. J.W. Rich (Augustus's Parthian honours..., s. 72) uznaje starania o zwrot signa za główny cel tej podróży Augusta na Wschód.

${ }_{15}$ RG, 27; Vell. Pat. II, 94; Jos., Ant. XV, IV, 3; Tac., Ann. II, 3, 4; Suet., Tib. 9; Cass. Dio LIV, 9 , 4-5; M. Zakrzewska-Dubasowa: Historia Armenii. Wrocław 1990, s. 33; B. Levick: Tiberius the Politician. London-New York 1999, s. 13-14; R. SeAger: Tiberius..., s. 14; P. SAwiŃski: Specjalni wystannicy cesarscy..., s. 48-49; E.S. GRUEN: The Expansion of the Empire under Augustus. W: CAH 10, s. 159; S. Payaslian: The History of Armenia. From Origins to Present. New York 2007, s. 231; H.L. KRYśKiewicz: Signa recepta..., s. 92-95.

${ }^{16}$ RG, 29; Vell. Pat. II, 91; Flor. II, 34; Suet., Aug. 21; Jus. XLII, 5, 10-12; Cass. Dio LIV, 8, 1-3; J. Wolski: Rzymska polityka na Wschodzie..., s. 92; A.D.H. Bivar: The Political History of Iran..., s. 66; W. Eck: The Age of Augustus. Singapore 2007, s. 126; E.S. Gruen: The Expansion..., s. 159-160; G. Traina: Imperial Views..., s. 213; T. Bryce: Ancient Syria..., s. 231-232; H.L. Kryśkiewicz: Signa recepta..., s. 95.

17 RG, 29; G. Traina: Imperial Views..., s. 213; H.L. Kryśkiewicz: Signa recepta..., s. 131. Rozważania na temat świątyni Marsa Mściciela zob. w: J.W. Rich: Augustus’s Parthian Honours..., s. 79-97. Początek kultu Marsa Ultora wiąże się z ostatnimi latami republiki. Jak wskazuje M. MıLCZANowsKi ( $W$ cieniu boskiego Juliusza..., s. 66) mogło mieć to związek bądź ze ślubowaniem triumwirów przed rozprawą z „tyranobójcami”, bądź z planami Cezara dotyczącymi dokonania zemsty na Partach za klęskę Krassusa.

${ }_{18}$ Przegląd definicji propagandy zaprezentowali m.in. O. Thomson: Historia propagandy. Tłum. S. GŁĄBIŃsKi. Warszawa 2001, s. 10-11; K. KopIJ w swej dysertacji doktorskiej Auctoritas et dignitas: studium prestiżu i propagandy w okresie późnej Republiki Rzymskiej na przykładzie rodu Pompejuszy (gens Pompeia Magna) w świetle źródeł archeologicznych i pisanych obronionej w 2015 roku na Uniwersytecie Jagiellońskim, s. 14-18. 
nego użycia tego pojęcia w badaniach nad starożytnością, kwestionują zasadność takiego jego wykorzystania ${ }^{19}$. Jednak bez względu na to, a także pomimo prób wprowadzenia do badań nowego pojęcia ${ }^{20}$, wielu badaczy wskazuje, że działania podejmowane przez antycznych Rzymian można określać jako „propagandę" ${ }^{21}$, z zastrzeżeniem podania odpowiedniego znaczenia tego słowa, aby uniknąć jego potocznego rozumienia czy emocjonalnej interpretacji ${ }^{22}$. W niniejszym artykule użyto terminu „propaganda” w znaczeniu: ,środek przejmowania albo ugruntowywania władzy, umacniania jej prestiżu oraz budowy lub wzmacniania autorytetu władcy"23, jako najlepiej oddającego intencje i działania rzymskich władz w odniesieniu do omawianej kwestii. Wiadomo zaś, że cesarz i związani z nim politycy nie o wszystkich swoich posunięciach, zwłaszcza natury wewnętrznej, mogli mówić otwarcie. Władcy potrzebne były także sukcesy. Nic więc dziwnego, że tak rozumianą propagandę stosowano bardzo często. Podobnie było z odzyskaniem signa, gdyż kwestia ta doskonale nadawała się do propagandowego wykorzystania.

Pierwsze aluzje, czy też obietnice, odnoszące się do podboju wschodniego sąsiada imperium uczynił Wergiliusz (P. Vergilius Maro) w swych Georgikach ${ }^{24}$. Poeta nie tylko wieszczył ujarzmienie Eufratu i Partów, lecz potraktował owe przyszłe zwycięstwa jako czyny godne ubóstwienia ich autora ${ }^{25}$.

Następnie temat wyeksponował Horacy w pierwszych trzech księgach Carmina. W I księdze wątek „partyjski” został poruszony w dwóch kontekstach. Jednym z nich była zapowiedź zwycięstwa. Poeta wieszczył bowiem triumf Augusta nad

${ }_{19}$ Użycie terminu „propaganda” w badaniach okresu cesarstwa rzymskiego kwestionują np. P. Veyne (Imperium grecko-rzymskie. Tłum. P. Domański. Kęty 2008) oraz P. Stewart (The Social History of Roman Art. Cambridge 2008).

${ }^{20}$ P. Veyne (Imperium...., s. 377-380) proponuje termin „przepych monarchiczny”.

${ }^{21}$ Zob. np.: N. Hannestad: Roman Art and Imperial Policy. Aarhus 1988, s. 9-10; J.E. Lendon: Empire of Honour. The Art of Government in the Roman World. Oxford 1997, s. 10-11; A.A. KLuCZEK: Studia nad propaganda polityczną w Cesarstwie Rzymskim II-III w. Toruń 2006; G.S. Jowett, V. O’Donnel: Propaganda and Persuasion. Los Angeles-London-New Delhi-Singapore-Washington DC 2012, s. 57-58; K. KopIJ: Auctoritas et dignitas... Na poezję jako nośnik politycznych idei władzy wskazuje również R. Syme (Rewolucja rzymska..., s. 254). Natomiast na ciągłą potrzebę promowania „nadnaturalnych atutów, wspaniałych zalet i nadzwyczajnych czynów” cesarza jako konsekwencję oparcia podstaw ustroju na „władzy charyzmatycznej” wskazują m.in. A.A. KLuczek: Studia nad propaganda..., s. 7; L. Morawiecki: Władza charyzmatyczna w Rzymie u schyłku Republiki (lata 44-27 p.n.e.). Poznań-Gniezno 2014, s. 28, 226.

${ }^{22} \mathrm{Na}$ takie rozumienie i konotacje interpretacyjne pojęcia „propaganda” wskazują m.in. N. Hannestad (Roman Art..., s. 9) oraz K. KopiJ (Auctoritas et..., s. 14, 29).

${ }^{23}$ Definicję przytoczono za: A.A. KLuczek: Studia nad propaganda..., s. 7.

${ }^{24}$ Verg., Georg. II, 114-174; III, 30-33; IV, 559-562. Georgiki zostały najprawdopodobniej ukończone w 29 roku p.n.e., zob. M. Сутоwsк A, H. Szelest: Literatura rzymska. Okres augustowski. Warszawa 1990, s. 108.

${ }^{25}$ J. Steenkamp: Vergil, Propertius, and the Euphrates. „Akroterion” 2010, 55, s. 65; H.L. KryśKIEWICZ: Signa recepta..., s. 154-155. 
„Medami” w dwóch wierszach zamieszczonych w tym zbiorze ${ }^{26}$. W obydwu przypadkach pokonanie wschodnich sąsiadów imperium zostało połączone z boskim posłannictwem tego władcy. W jednym wierszu Horacy zasugerował, że pokonanie Partów przyczyni się do chwały cesarza ${ }^{27}$, natomiast w drugim - że boska opieka sprawi, iż zostaną pokonani wszyscy wrogowie Rzymu, który zatriumfuje nie tylko nad Partami, lecz także nad egzotycznymi plemionami Indów i Serów (Chińczyków) $^{28}$. Wydaje się więc, że zapowiedzi rychłego pokonania wschodnich sąsiadów Rzymu były skierowane zarówno do rządzących, jak i rządzonych. Wskazuje to na „oddolną" inicjatywę powstania obu wierszy oraz na to, że potrzeba zemsty na Partach była zakorzeniona w rzymskim społeczeństwie ${ }^{29}$.

We wspomnianej I księdze Pieśni motyw odwetu na wschodnich sąsiadach Rzymu pojawił się jeszcze w innym kontekście. Horacy w dwudziestym pierwszym wierszu tego zbioru wzywa śpiewające chóry do gorliwszego czczenia Diany i Apolla, aby w zamian odwrócili oni wojnę i zarazę od Rzymu, a zesłali ją na Persów i Brytów ${ }^{30}$. Wiersz ten można interpretować dwojako. Z jednej strony Apollo, bóg, z którym August się najbardziej identyfikował, mógł odwrócić nieszczęścia z uwagi na swego protegowanego, pokonanie Partów byłoby zatem zasługą cesarza. Można również wysnuć wniosek, że wróg ze Wschodu był na tyle potężny, że bez boskiej pomocy nie sposób go pokonać, czego dowodem była klęska Krassusa, który wyruszył pod Carrhae nie tylko bez odpowiednich auspicjów, lecz nawet pod ciężarem klątwy ${ }^{31}$. W przeciwieństwie jednak do niego, August dbał o pokój boży, czym zapewnił błogosławieństwo swym planom.

Horacy powrócił do tematu zemsty na Partach także w III księdze Pieśni. Powstawała ona w okresie, gdy rozważano pewne działania wobec wschodniego sąsiada $^{32}$. W piątym wierszu tego zbioru poeta rozwinął temat jeńców pojmanych w trakcie wyprawy Krassusa. Wyraził mianowicie dezaprobatę wobec potencjalnego ich powrotu do ojczyzny. Przez odwołanie się do przeszłości, zwłaszcza do postaci Regulusa (M. Atilius Regulus) ${ }^{33}$, Horacy zanegował zasadność starań

26 Hor., Car. I, 2, 45-53; I, 12, 53-56.

27 Ibidem, I, 2, 45-53; T. BABnis: Persowie, Medowie, Partowie w Pieśniach Horacego. „Nowy Filomata" 2016, 20, 2, s. 175-176.

${ }^{28}$ Hor., Car. I, 12, 49-60; G. Traina: Imperial Views..., s. 213; T. Babnis: Persowie, Medowie, Partowie..., s. 177.

${ }^{29}$ J.W. Rich: Augustus's Parthian Honours..., s. 72.

30 Hor., Car. I, 21; T. Babnis: Persowie, Medowie, Partowie..., s. 177.

${ }^{31}$ Krassus podjął wojnę z Partami mimo przyjaźni łączącej ich z Rzymem oraz niepomyślnych znaków towarzyszących jego wyjazdowi. W związku z tym wyprawie usiłowali zapobiec trybunowie, m.in. Gajusz Atejusz (C. Ateius Capito), lecz mimo tego triumwir wyruszył do Syrii (Cic., Div. I, 29; Vell. Pat. II, 46; Plut., Crass. 16; App., BC II, 18; Cass. Dio XXXIX, 39, 6).

${ }^{32}$ Czyli niedługo przed 23 rokiem p.n.e.

33 T. Babnis: Persowie, Medowie, Partowie..., s. 181-182. 
o ich powrót. Włożył w usta tego wodza wiele argumentów przeciwko repatriacji jeńcó $w^{34}$, m.in. fakt, że pojęli oni za żony barbarzyńskie kobiety ${ }^{35}$. Horacy $\mathrm{z}$ tego więc względu odradzał władcy starania o sprowadzenie dawnych legionistów do ojczyzny.

W podobnym tonie wyrażał się Propercjusz. W elegiach trzykrotnie nawiązał do zemsty za klęskę Krassusa i utratę znaków legionowych. Najszerzej uczynił to w czwartym poemacie III księgi ${ }^{36}$. Opisał w nim zamierzenia Augusta i wzywał Rzymian do czynnego udziału w nich ${ }^{37}$. Plany te obejmowały wojnę na Wschodzie, w trakcie której miano dokonać zemsty na Partach oraz odzyskać znaki legionowe $^{38}$. Ponadto cesarz miał ujarzmić Tygrys i Eufrat. Przewidywano, że walki będą się toczyć nawet z ludami Indiii ${ }^{39}$. Poeta kreślił więc wizję światowej dominacji Rzymu, której gwarantem był August. Poza zapewnianiem ludu o takim obrocie spraw Propercjusz - w piątym poemacie zbioru elegii - zachęcał również władcę do odzyskania signa ${ }^{40}$.

Podsumowując, należy stwierdzić, że autorzy wierszy napisanych przed 20 rokiem p.n.e. kreowali obraz oczekiwań wobec polityki wschodniej Augusta. Poeci w swych przekazach wzywali cesarza do zemsty na Partach i odebrania im legionowych signa. Oczywiście nie można wykluczyć, że dokonanie odwetu za klęskę pod Carrhae było szeroko omawiane przez ówczesnych Rzymian ${ }^{41}$. Jednak włączenie w treść wzmiankowanych poematów idei przyszłego władztwa światowego zdaje się świadczyć, że źródło inspiracji owych poematów było nie tylko oddolne, lecz także odgórne.

Poeci bowiem wobec możliwego spadku popularności cesarza, w wyniku niekorzystnej sytuacji w państwie i na jego granicach przed 20 rokiem p.n.e. ${ }^{42}$, swoimi przekazami budowali w społeczeństwie poczucie, że mimo przejściowych trudności Rzym pod rządami predestynowanego do boskości władcy czeka wielka przyszłość i chwała. Zgodnie również wskazywali, że istotnym elementem owej drogi była zemsta na Partach.

Po odzyskaniu przez Augusta znaków legionowych w rzymskiej poezji wyróżnić można drugi okres propagowania odwetu za klęskę Krassusa i utracenie

\footnotetext{
${ }^{34}$ Hor., Car. III, 5, 9-40.

35 Ibidem, III, 5, 5-12; T. Babnis: Persowie, Medowie, Partowie..., s. 181-182.

36 Prop. III, 4; G. Traina: Imperial Views..., s. 213.

37 Ibidem, III, 4, 1-9.

38 T. BABNis (Augustan Poets on the Roman-Parthian Treaty of 20 BC. „Classica Cracoviensia” 2017, 20, s. 22) wskazuje na sakralne konotacje dokonanej zemsty.

39 Prop. III, 4, 1-9.

${ }^{40}$ Ibidem, III, 5, 17-18. Autor ten nawiązuje do klęski Krassusa także w II, 10, 13-16.

${ }^{41}$ H.L. Kryśkiewicz: Signa recepta..., s. 159, 167-168.

42 J.A. Crook: Political History..., s. 75-79, 87; E.S. Gruen: The Expansion..., s. 148-151, $163-166$.
} 
owych signa. W nowych realiach temat „partyjski” jako pierwszy podjął Horacy. W 20 roku p.n.e. opublikował on pierwszą księgę swoich listów ${ }^{43}$. W jednym z nich, skierowanym do Ikcjusza, zamieścił spis najważniejszych, jego zdaniem, ówczesnych wydarzeń politycznych ${ }^{44}$. Według poety rzymskiej władzy poddali się wówczas Kantabrowie $^{45}$, Armenia i Partia. Takie ujęcie tej kwestii wraz z jej opisem ${ }^{46}$ tworzą $^{2}$ wrażenie nie bilateralnego układu między Rzymianami a Partami, lecz wręcz hołdu poddańczego złożonego Augustowi przez Partów ${ }^{47}$. W ten sposób porozumienie dyplomatyczne ukazano jako zwycięstwo militarne ${ }^{48}$.

Horacy wspomniał o osiągnięciach Augusta również w liście skierowanym do Lolliusza $^{49}$. Nadmienił w swych wywodach, że adresat poematu walczył przeciwko Kantabrom pod rozkazami wodza, który odebrał rzymskie signa legionowe Partom oraz przyrzekł podbić inne krainy ${ }^{50}$. Sugeruje to, że Horacy zemstę za klęskę Krassusa oraz utracone przez niego znaki postrzegał jako warunek następnych zwycięstw. Przywrócona pax deorum zapewniała bowiem błogosławieństwo dalszym działaniom cesarza. Ta konkluzja miała sugerować Rzymianom, że okres klęsk i katastrof skończył się wraz z sukcesem Augusta.

Wówczas wydano także Eneidę, ostatnie dzieło Wergiliusza. Poeta zamieścił w niej dwa odniesienia do zwrotu rzymskich signa legionowych przez Partów. Pierwsze zawiera jedynie wzmiankę $e^{51}$, w której autor symbolicznie oznajmił czytelnikom, że zostanie stoczony zwycięski konflikt o odzyskanie tych signa. Ponownie Wergiliusz wspomniał o pokonaniu Partów w księdze VIII Eneidy ${ }^{52}$. Poza wschodnimi sąsiadami imperium jako ujarzmione przez Augusta zostały wymienione również inne ludy. Łączy to Eneidę z pozostałymi poematami z epoki Augusta, w których głoszono wizję dominacji Rzymu nad innymi krajami i ludami.

Także Propercjusz w ostatniej księdze Elegii odniósł się do zwrotu utraconych pod Carrhae signa. Poeta opisał w swym wierszu wielką ucztę, podczas której zebrani weselili się z odniesionych przez Rzymian zwycięstw ${ }^{53}$. Wśród nich wzmiankowany był również rychły zwrot znaków legionowych ${ }^{54}$. Autor w tym poemacie

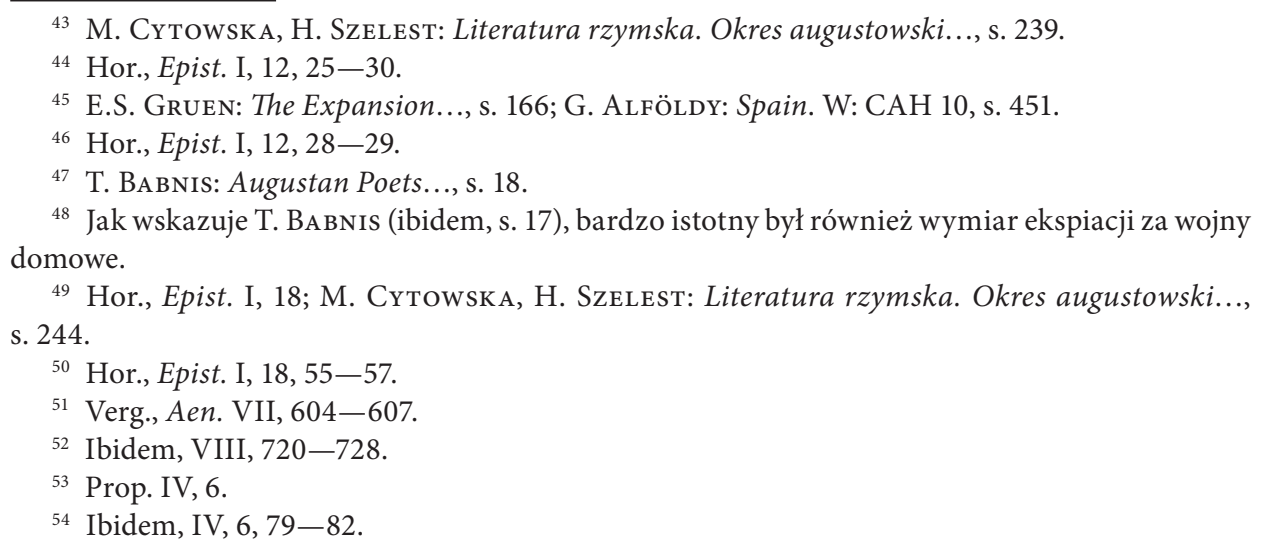


zamieścił także odniesienie do nieżyjącego Krassusa, którego wzywał do radowania się, gdyż Rzymianie mogli przez Eufrat kroczyć do jego mogily ${ }^{55}$.

Horacy natomiast do tematyki powiązanej ze zwrotem przez Partów znaków legionowych wrócił w ostatniej księdze Carmina. Odniesione po 20 roku p.n.e. zwycięstwa ${ }^{56}$ sprawiały, że - wedle Horacego - Rzymian i ich państwo czekała wielka przyszłość i nie musieli się już nikogo obawiać ${ }^{57}$. Poeta wymienił m.in. Partów jako lud, który dawniej mógł wzbudzać trwogę ${ }^{58}$. Natomiast w innym poemacie przypomniał, że los w kolejnych 15 latach po zdobyciu Aleksandrii sprzyjał Augustowi, pomagając mu ujarzmić m.in. Medów ${ }^{59}$. W następnym utworze Horacy wychwalał Augusta i jego panowanie ${ }^{60}$. Jako jedno z ówczesnych dokonań władcy potraktował oczywiście omawiany zwrot znaków legionowych przez Partów ${ }^{61}$. Jego zdaniem, o potędze owego władcy świadczył również posłuch, jakim się cieszył wśród ludów sąsiadujących $z$ Rzymem i innych, m.in. Persów ${ }^{62}$. Podobne nawiązania do dominacji imperium nad całym światem znaleźć można w pieśni skomponowanej na obchody ludi saeculares ${ }^{63}$.

Owidiusz także nawiązał w swoich utworach do odzyskania znaków legionowych utraconych przez Krassusa. W Ars amatoria poeta, odnosząc się do przyszłego pochodu triumfalnego wnuka Augusta - Gajusza Cezara (C. Iulius Caesar), wspomniał również o odzyskaniu signa w 20 roku p.n.e. ${ }^{64}$

Ponownie zwrot znaków legionowych został poruszony w Fasti. Po raz pierwszy w księdze V, we fragmencie dotyczącym świątyni Marsa Mściciela, gdzie signa zostały ostatecznie w 2 roku p.n.e. na stałe złożone ${ }^{65}$. Passus ten jest stosunkowo długi, poeta odmalował w nim wszystkie okoliczności towarzyszące złożeniu znaków w przybytku. Dokładnie przedstawił klęskę Krassusa i jej konsekwencje ${ }^{66}$. Jednak sam opis odzyskania znaków przez Augusta jest mniej dokładny. Ta lakoniczność, wespół z budową fragmentu, w którym autor zwrócił się bezpośrednio do wroga ${ }^{67}$,

\footnotetext{
55 Ibidem, 6, 83-84.

${ }^{56}$ W 19 roku p.n.e. podbito Hiszpanię, a rok wcześniej narzucono władcę Armenii oraz odzyskano signa legionowe utracone przez Krassusa pod Carrhae.

57 T. Babnis: Augustan Poets..., s. 19-21.

58 Hor., Car. IV, 5, 25-28; T. Babnis: Persowie, Medowie, Partowie..., s. 183.

59 Hor., Car. IV, 14, 34-44; T. Babnis: Persowie, Medowie, Partowie..., s. 183.

60 Hor., Car. IV, 15.

${ }^{61}$ Ibidem, IV, 15, 6-8. Również T. Babnis (Persowie, Medowie, Partowie..., s. 183) wskazuje na znaczenie, jakie Horacy nadaje temu wydarzeniu.

62 Hor., Car. IV, 15, 21-24; T. Babnis: Persowie, Medowie, Partowie..., s. 183.

${ }^{63}$ Hor., Car. Saec. 53-56; T. Babnis: Persowie, Medowie, Partowie..., s. 183.

64 Ovid., Ars I, 179-180.

65 Ovid., Fast. V, 550-598.

${ }^{66}$ Ibidem, V, 580-586; T. BABNis: Augustan Poets..., s. 30-31.

67 Ovid., Fast. V, 591-594.
} 
sprawiły, że odbiorca ma wrażenie, iż cesarz odniósł wielkie zwycięstwo militarne, a nie tylko dyplomatyczny sukces ${ }^{68}$.

Podobny wydźwięk ma fragment zamieszczony w księdze VI. Zaczyna się on od przypomnienia bitwy pod Carrhae ${ }^{69}$. W następnych wersach ustami bogini Westy autor zwrócił się bezpośrednio do Partów ${ }^{70}$. Użyte w nich sformułowania ponownie sugerują, że August odniósł nad wrogiem zwycięstwo militarne. Służyły więc one umocnieniu wrażenia, że Partowie zostali pokonani i byli gotowi do słuchania rozkazów władcy Rzymu.

W poematach pisanych na wygnaniu Owidiusz również nawiązał do zwrotu znaków legionowych utraconych przez Krassusa. W jednym z fragmentów listu skierowanego do Augusta autor wymienił jego osiągnięcia ${ }^{71}$. Poza odzyskaniem znaków legionowych Owidiusz wskazał na zwycięstwa odniesione przez cesarza m.in. w Ilirii czy Germanii ${ }^{72}$. Zbudował więc listę najważniejszych, w domyśle militarnych, sukcesów władcy, a zarazem przedstawił ponownie wizję światowego władztwa Rzymu, choć w mniejszej niż dotychczas skali.

Podsumowując rozważania, można stwierdzić, że po 20 roku p.n.e. poeci wykorzystywali motyw zwrotu znaków legionowych w kilku kontekstach, jako:

- namacalny symbol zemsty na Partach za dawne krzywdy i upokorzenia (wówczas wspominano również klęskę Krassusa ${ }^{73}$ pod Carrhae),

— jeden z warunków uzyskania przez Rzym władzy nad światem,

- zwycięstwo militarne.

Spośród poetów najczęściej do zwrotu signa odnosił się Horacy, który przede wszystkim przedstawiał ten sukces jako świetne zwycięstwo wojskowe oraz przyczynek do zdobycia przez Rzym władztwa bez granic lub jego element. Podobnie czynił Wergiliusz. Propercjusz natomiast poza fetowaniem zwycięstwa odnosił się także do dawnej klęski Krassusa. Owidiusz w różnych swych utworach nawiązywał do odzyskania znaków w każdym z trzech wymienionych rodzajów odniesień.

Z dokonanej analizy poezji epoki augustowskiej wyłania się obraz pewnej interpretacji wydarzeń, jaką postanowiono propagować wśród Rzymian. Cesarz pragnął bowiem, żeby jego sukces dyplomatyczny fetowano jako wielkie zwycięstwo mili-

\footnotetext{
68 Podobnie również T. BABnis (Augustan Poets..., s. 31-32).

69 Ovid., Fast. VI, 465-466; T. BABNis: Augustan Poets..., s. 33.

${ }^{70}$ Ovid., Fast. VI, 467-468.

${ }^{71}$ Ovid., Trist. II, 225-230.

72 Ibidem.

73 Postrzeganie Krassusa w literaturze oraz historiografii antycznej było wynikiem zabiegów propagandowych Augusta i jego następców. Ów wizerunek związany był z wieloma czynnikami, m.in. z omawianą w niniejszym artykule kwestią odzyskania znaków legionowych, i podlegał pewnej ewolucji. Szerzej na ten temat zob.: G. Traina: Imperial Views..., s. 213-216; N.L. Overtoom: The Partian Rival and Rome's Failure in the East: Roman Propaganda and the Stain of Crassus. „Acta Antiqua Academiae Scientiarum Hungaricae” 2017, 57, s. 1-22.
} 
$\operatorname{tarne}^{74}$. Aby potwierdzić, że ten wykreowany w literaturze pięknej obraz stanowił jedyny sposób wykorzystania w czasach panowania Augusta faktu odzyskania legionowych signa utraconych pod Carrhae, należy się również przyjrzeć źródłom numizmatycznym i ikonograficznym.

Nawiązania do porozumienia $\mathrm{z}$ Partią pojawiały się na monetach wybijanych w latach 19-18 p.n.e. w imperium rzymskim zarówno na wschodzie, zachodzie, jak i w stolicy państwa.

W mennicach hiszpańskich dominowały dwa główne typy monet odnoszących się do zwrotu signa. Pierwszy zawierał na rewersach napis: SIGNIS RECEPTIS oraz wyobrażenie Marsa trzymającego znaki legionowe ${ }^{75}$. Drugi typ był natomiast bardziej metaforyczny - składał się z napisu: MARTIS ULTORIS (bądź odpowiedniej abrewiacji), a zamieszczona na numizmatach ikonografia przedstawiała świątynię Marsa ze złożonymi w niej sztandarami ${ }^{76}$. Zauważyć można, że od samego niemalże początku zwrot znaków legionowych straconych przez Krassusa pod Carrhae, zarówno w mennictwie, jak i polityce, był łączony z kultem Marsa Mściciela $^{77}$. Zwieńczeniem tych koneksji było ostatecznie umieszczenie signa w świątyni tego boga.

Osobną kwestią pozostaje umiejscowienie budynku wyobrażonego na wspomnianych monetach. John W. Rich podjął się rozwiązania tego problemu ${ }^{78} . \mathrm{Na}$ podstawie wielu przesłanek wysunął hipotezę, że senat na wieść o sukcesie Augusta uchwalił wzniesienie świątyni Marsa Ultora na Kapitolu ${ }^{79}$, władca jednak nie zgodził się na to rozwiązanie i zmienił lokalizację przybytku na nowe forum (Forum Augustum $)^{80}$.

Podobne legendy, jak na już omówionych numizmatach, znajdują się również na monetach pochodzących z Azji Mniejszej. Występują bowiem na nich abrewiacje słów MARTIS ULTORIS ${ }^{81}$, a także wariacje inskrypcji SIGNIS RECEPTIS ${ }^{82}$. Pierwszy z wymienionych typów jest opatrzony ikonografią przedstawiającą świątynię Marsa Ultora. Natomiast część monet z legendą SIGNA RECEPTA zawiera wyob-

${ }^{74}$ J.W. Rich: Augustus's Parthian Honours..., s. 73; T. BABnis: Augustan Poets..., s. 36-37; H.L. Kryśkiewicz: The Parthians in the Ist c. B.C. - a Worth Enemy of Rome? Remarks on the Issue of Roman-Parthian Political Conflict in the Ending Period of Existence of the Roman Republic, and on Its Influence on Roman Imperial Ideology. „The World of the Orient (Shidnyj Svit)” 2017, 3, s. 66 .

${ }^{75}$ Na przykład RIC I, nr 41, 58, 60, 80a, 80b, 82a, 82b, 83, 84.

${ }_{76}$ Na przykład RIC I, nr 28, 39a, 39b, 68, 69a, 69b, 70a, 70b, 71, 72, 73, 74a, 74b.

77 J.W. RICH (Augustus's Parthian honours..., s. 87-88) spekuluje, że August przed wyjazdem na Wschód ogłosił, że odzyskane znaki legionowe będą dedykowane Marsowi Ultorowi.

${ }^{78}$ J.W. Rich: Augustus's Parthian honours..., s. 79-97.

79 Informację taką podał Kasjusz Dion (LIV, 8, 3).

${ }^{80}$ J.W. Rich: Augustus's Parthian Honours..., s. 86-89.

${ }^{81}$ RIC I, nr 507.

${ }^{82}$ RIC I, nr 508, 509, 510, 521, 522, 523, 524, 525, 526. 
rażenie łuku triumfalnego, którego wzniesienie, w dowód uznania dla Augusta za odzyskanie znaków legionowych, zostało uchwalone przez senat ${ }^{83}$.

Na wspomnianych monetach zostały więc uwiecznione budowle, które miały gloryfikować dokonania princepsa, czyli pełniły funkcję propagandową. Taka ich rola wynikała z dwóch elementów. Po pierwsze, umieszczone na nich rozliczne ozdoby, a także inskrypcje informowały odbiorcę o dokonaniach władcy ${ }^{84}$. Po drugie, wydaje się, że równie istotny był sam rozmiar budowli ${ }^{85}$. Swoją wielkością świadczyły one o potędze cesarza oraz dowodziły, że czyn, dla którego upamiętnienia i uczczenia je wzniesiono, był tego godny.

Z kolei numizmaty wybite w Rzymie w 19 roku p.n.e. ${ }^{86}$ przedstawiają na rewersie postać klęczącego Parta, oddającego znak legionowy. Monety z innych części imperium informowały o sukcesie Augusta zarówno dosłownie, jak i metaforycznie. Natomiast te wyemitowane wówczas w stolicy niosły znacznie obszerniejszą treść. Za ich pomocą bowiem władca pokazywał, że Partowie zostali pokonani oraz zmuszeni do pokłonu.

Jak zauważa Paul Zanker, motyw klęczącego barbarzyńcy stał się wówczas bardzo popularny wśród Rzymian. Do tego stopnia, że wizerunek ten był wykorzystywany np. na pierścieniach ${ }^{87}$. Zaadaptowano go również w „oficjalnej” sztuce. Doskonałym tego przykładem jest rzeźba Augusta z willi Liwii w Prima Porta, wykonana po 20 roku p.n.e. ${ }^{88}$ Przedstawia ona cesarza ubranego w pancerz. W centralnym punkcie napierśnika władcy umieszczono scenę przekazania przez króla Partów znaków legionowych przedstawicielowi Rzymian ${ }^{89}$. W tym przypadku nie można oczywiście mówić o postaci klęczącego barbarzyńcy, jednak ułożenie postaci i cały kontekst tej sceny ${ }^{90}$ wskazują na nadrzędną pozycję Rzymianina. Za pomocą rzeźby ukazano Augusta jako wielkiego władcę i wodza, a jako jego najważniejsze dokonanie — odzyskanie signa z rąk Partów. To wydarzenie bowiem, jak ukazywali

${ }^{83}$ O tym zaszczycie wzmiankował, podobnie jak o wcześniej opisywanej świątyni, Kasjusz Dion (LIV, 8, 4). Monety z wyobrażeniem tego monumentu wybijano również w Hiszpanii (RIC I, $\mathrm{nr} 131-137)$. Hipotetyczny łuk triumfalny zrekonstruowany został przez N. Hannsteada (Roman Art..., s. 59-60). Tymczasem J.W. RICH (Augustus's Parthian Honours..., s. 97-115) wysuwa hipotezę, że osobny monument ku czci zwycięstwa nad Partami nigdy nie powstał.

${ }^{84}$ Zob. m.in. rewersy podanych w artykule monet oraz proponowane rekonstrukcje łuku i świątyni w opracowaniach N. Hannsteada (Roman Art..., s. 59-60, 83-90) i J.W. Rich A (Augustus's Parthian Honours..., s. 79-115).

${ }^{85} \mathrm{Na}$ propagandowe cechy architektury zwraca uwagę K. KopIJ: Auctoritas et dignitas..., s. $37-38$.

${ }^{86}$ RIC I, nr 287, 288, 289, 304, 305, 314, 315.

${ }^{87}$ P. ZANKER: The Power of Images..., s. 187.

${ }^{88}$ N. Hannestad: Roman Art..., s. 50-51; P. Zanker: The Power of Images..., s. 188.

${ }^{89}$ N. Hannestad: Roman Art..., s. 52-55; P. Zanker: The Power of Images..., s. 189.

90 Scenę przedstawioną na tym napierśniku omawiają m.in. N. Hannestad (Roman Art..., s. 52-56) oraz P. Zanker (The Power of Images..., s. 189-192). 
poeci, stanowiło warunek dalszych podbojów. Należy też zauważyć, że w omawianej scenie uczestniczą istoty nadprzyrodzone. P. Zanker wyróżnia Niebo, Ziemię, Apolla, Dianę, bóstwa astralne oraz Sfinksy ${ }^{91}$. Razem symbolizują one wieczność, boski porządek oraz strażników świata i samego władcy ${ }^{92}$.

W kontekście dzieł sztuki, takich zwłaszcza jak wzmiankowane pierścienie czy posągi, które niekoniecznie były związane z fundacjami cesarskimi, pojawiają się wątpliwości, czy można je traktować jako przekaz propagandowy. Jak stwierdza Kamil Kopij, na podstawie badań teoretyków propagandy, istnieją jednak ku temu podstawy ${ }^{93}$. Sugeruje on bowiem, że odbiorcy propagandy, czyli np. senatorowie, przekazywali te informacje dalej dla osiągnięcia własnych celów. Nieświadomie więc powielali przekaz władcy — czy to wobec mieszkańców prowincji, czy samych Rzymian - czyniąc jego wydźwięk jeszcze intensywniejszym ${ }^{94}$.

Podsumowując poczynione rozważania, można dostrzec kilka podstawowych cech propagandowego wykorzystania odzyskania znaków legionowych utraconych przez Krassusa w wyniku klęski pod Carrhae. Po pierwsze, należy zauważyć, że postać triumwira i jego porażka były ukazywane stosunkowo rzadko. W przekazie propagandowym czyniono to tylko w celu podkreślenia wielkości zemsty, jakiej August dokonał na Partach.

Sam fakt odzyskania znaków legionowych wykorzystywano w propagandzie częściej. Eksponowano to jako wielki sukces, stanowiący ważny przyczynek dla chwały Augusta. Propagowaniu tego wydarzenia służyły wiersze opublikowane niedługo po 20 roku p.n.e. oraz monety, na których wyobrażono zaszczyty uchwalone dla władcy w związku z tym wydarzeniem.

Równocześnie zwrot signa przez Partów był formą rewanżu za dawną klęskę. Porozumienie dyplomatyczne zawarte $\mathrm{z}$ nimi, dla podkreślenia elementu odwetowego, ukazywano więc jako wielkie zwycięstwo, w domyśle militarne. To natomiast przerodziło się w ukazywanie wschodnich sąsiadów Rzymu jako pokonanych, ujarzmionych oraz oczekujących poleceń Augusta. Obraz ten jest częsty w poezji, numizmatyce i sztuce.

Ów sukces był fetowany także w bardziej metaforycznym sensie. Otóż odzyskanie znaków legionowych utraconych pod Carrhae przez Krassusa było przywróceniem wspólnoty $\mathrm{z}$ istotami boskimi, ponownym zawarciem pokoju bożego. W konsekwencji wiązało się z odzyskaniem przychylności bóstw i zmyciem hańby za wojny domowe. Te sakralne elementy były bowiem warunkiem dalszych, większych sukcesów rzymskich.

\footnotetext{
${ }^{91}$ P. ZAnker: The Power of Images..., s. 189-192.

92 Ibidem.

${ }^{93}$ K. Kopis: Auctoritas et dignitas..., s. 31-32.

${ }^{94}$ Ibidem.
} 
Ważne jest również powiązanie zwrotu omawianych w artykule znaków legionowych z kultem Marsa Mściciela. Numizmaty z tym odniesieniem pojawiły się już w 19 roku p.n.e. i, jak wskazuje J.W. Rich, August najprawdopodobniej jeszcze przed wyruszeniem na Wschód zapowiedział ofiarowanie odzyskanych sztandarów owemu bóstwu ${ }^{95}$. Związki te mogły więc być dwojakiego rodzaju. Z jednej strony, jeżeli rzeczywiście kult Marsa Ultora został zapoczątkowany przez Oktawiana, Antoniusza i Lepidusa (M. Aemilius Lepidus) przed wojną z Brutusem (M. Iunius Brutus) i Kasjuszem (C. Cassius Longinus), to poprzez rozszerzenie rozumienia kultu tego bóstwa na szerzej pojętą zemstę, odwet na Partach za klęskę Krassusa można było naturalnie z nim powiązać. Jednak, jak wspomniano, Maciej Milczanowski sugeruje, że już Cezar mógł odwoływać się do tego bóstwa właśnie w kontekście organizowanej przez niego wyprawy na Wschód ${ }^{96}$. Podobnie uważa J.W. Rich ${ }^{97}$. Być może więc zadedykowanie oczekiwanego zwycięstwa nad Partami i odzyskanie utraconych w 53 roku p.n.e. signa temu bogu, a także późniejsza budowa jego świątyni, m.in. jako nowego miejsca przechowywania spolia opima ${ }^{98}$, były hołdem dla Cezara oraz wyrazem pietas Augusta. W takim kontekście w 2 roku p.n.e. poprzez dedykację nowej świątyni Marsowi Ultorowi cesarz symbolicznie wypełnił ostatnią z obietnic swego przybranego ojca.

\section{Bibliografia}

Alföldy G.: Spain. W: Cambridge Ancient History. Vol. 10: The Augustan Empire, 43 B.C.-A.D. 69. Eds. A.K. Bowman, E. Champlin, A. Lintott. Cambridge 2008, s. 449-463.

Babnis T.: Augustan Poets on the Roman-Parthian Treaty of 20 BC. „Classica Cracoviensia” 2017, 20, s. $5-44$.

Babnis T.: Persowie, Medowie, Partowie w Pieśniach Horacego. „Nowy Filomata” 2016, 20, 2 , s. $175-176$.

BArrett A.A.: Livia First Lady of Imperial Rome. New Haeven-London 2002.

Bivar A.D.H.: The Political History of Iran under the Arsacids. W: The Cambridge History of Iran. Vol. 3.1: The Seleucid, Parthian and Sasanian Periods. Ed. E. Yarshater. Cambridge 2006, s. $21-99$.

Bryce T.: Ancient Syria. A Three Thousand Year History. New York 2014.

Cagniart P.: The Late Republican Army (146-30 BC). W: A Companion to the Roman Army. Ed. P. Erdkamp. Malden-Oxford-Carlton 2007, s. 80-95.

Crook J.A.: Political History, 30 B.C. to A.D. 14. W: Cambridge Ancient History. Vol. 10: The Augustan Empire, 43 B.C.-A.D. 69. Eds. A.K. Bowman, E. Champlin, A. Lintott. Cambridge 2008, s. $70-112$.

\footnotetext{
${ }^{95}$ J.W. Rich: Augustus's Parthian Honours..., s. 88.

${ }_{96}$ M. Milczanowski: W cieniu boskiego Juliusza..., s. 66.

${ }_{97}$ J.W. Rich: Augustus's Parthian Honours..., s. 87-88.

${ }_{98}$ Ibidem, s. 89-97.
} 
Cytowska M., Szelest H.: Literatura rzymska. Okres augustowski. Warszawa 1990.

Eck W.: The Age of Augustus. Singapore 2007.

Edwell P.: The Euphrates as a Boundary between Rome and Parthia in the Late Republic and Early Empire. „Antichthon” 2013, 47, s. 191-206.

Gruen E.S.: The Expansion of the Empire under Augustus. W: Cambridge Ancient History. Vol. 10: The Augustan Empire, 43 B.C.-A.D. 69. Eds. A.K. Bowman, E. Champlin, A. Lintott. Cambridge 2008, s. 147-197.

Hannestad N.: Roman Art and Imperial Policy. Aarhus 1988.

HöLscher T.: Sztuka rzymska: język obrazowy jako system semantyczny. Tłum. L. Olszewski. Poznań 2011.

Huzar E.G.: Mark Anthony. A Biography. Minneapolis 1979.

Jowett G.S., O’Donnel V.: Propaganda and Persuasion. Los Angeles-London-New Delhi 2012.

Камм A.: Julius Caesar. A life. London-New York 2006.

Keppie L.: The Making of the Roman Army. From Republic to Empire. London 2005.

KLUCZeK A.A.: Studia nad propaganda polityczna w Cesarstwie Rzymskim II-III w. Toruń 2006.

KopIj K.: Auctoritas et dignitas: studium prestiżu i propagandy w okresie późnej Republiki Rzymskiej na przykładzie rodu Pompejuszy (gens Pompeia Magna) w świetle źródeł archeologicznych i pisanych. Praca doktorska, Uniwersytet Jagielloński 2015.

Koshelenko G.A., Pilipko V.N.: Parthia. W: History of Civilizations of Central Asia. Vol. 2: The Development of Sedentary and Nomadic Civilizations: 700 B.C. to A.D. 250. Eds. J. HarmatTa, B.N. Puri, G.F. ETemadi. Paris 1996, s. 131-150.

KryśKIEwicz H.L.: Signa recepta w starożytnym Rzymie 20 roku przed Chrystusem. Kontekst polityczny oraz ideologiczny sukcesu. Szczecin 2016.

Kryśkiewicz H.L.: The Parthians in the Ist c. B.C. - a Worth Enemy of Rome? Remarks on the Issue of Roman-Parthian Political Conflict in the Ending Period of Existence of the Roman Republic, and on Its Influence on Roman Imperial Ideology. „The World of the Orient (Shidnyj Svit)” 2017, 3, s. $60-72$.

LENDON J.E.: Empire of Honour. The Art of Government in the Roman World. Oxford 1997.

Levick B.: Tiberius the Politician. London-New York 1999.

MADEJSki P.: Pomiędzy robur animi a ritus barbarus: zemsta $w$ życiu społecznym republikańskiego Rzymu. Lublin 2018.

Milczanowski M.: W cieniu boskiego Juliusza. Imię Cezara w propagandzie u schytku Republiki. Kraków 2013.

Morawiecki L.: Władza charyzmatyczna w Rzymie u schyłku Republiki (lata 44-27 p.n.e.). Poznań-Gniezno 2014.

Ostrowski J.A.: Starożytny Rzym. Polityka i sztuka. Warszawa-Kraków 1999.

Overtoom N.L.: The Partian Rival and Rome's Failure in the East: Roman Propaganda and the Stain of Crassus. „Acta Antiqua Academiae Scientiarum Hungaricae” 2017, 57, s. 1-22.

Payaslian S.: The History of Armenia. From Origins to Present. New York 2007.

Pelling Ch.: The Triumviral Period. W: Cambridge Ancient History. Vol. 10: The Augustan Empire, 43 B.C. - A.D. 69. Eds. A.K. Bowman, E. Champlin, A. Lintott. Cambridge 2008, s. 1-69.

PopŁAwski M.S.: Bellum Romanum. Sakralność wojny i prawa rzymskiego. Lublin 2011.

Rawson E.: Caesar: Civil War and Dictatorship. W: Cambridge Ancient History. Vol. 9: The Last Age of Roman Republic, 146-43 B.C. Eds. J.A. Сrook, A. Lintott, E. Rawson. Cambridge 2008, s. $424-467$.

Rich J.W.: Augustus's Parthian Honours, the Temple of Mars Ultor and the Arch in the Forum Romanum. „Papers of the British School at Rome” 1998, 66, s. 71-128. 
SAwIŃski P.: Specjalni wysłannicy cesarscy od Augusta do Tyberiusza. Studium nad początkami pryncypatu. Poznań 2005.

Scullard H.H.: From the Gracchi to Nero: A History of Rome 133 BC to AD 68. London-New York 2010.

Seager R.: Tiberius. Bodmin 2005.

Southern P.: Oktawian August. Tłum. D. Kozińska. Warszawa 2003.

Southern P.: The Roman Army. A Social and Institutional History. Santa Barbara-DenverOxford 2006.

Steenkamp J.: Vergil, Propertius, and the Euphrates. „Akroterion” 2010, 55, s. 61-74.

Stewart P.: The Social History of Roman Art. Cambridge 2008.

Stoll O.: The Religions of the Armies. W: A Companion to the Roman Army. Ed. P. ERdKamp. Malden-Oxford-Carlton 2007, s. 451-476.

Syme R.: Rewolucja rzymska. Tłum. A. Baziór. Poznań 2009.

Thomson O.: Historia propagandy. Tłum. S. GŁąBiński. Warszawa 2001.

Traina G.: Imperial Views on the Battle of Carrhae. W: War in Words. Transformations of War from Antiquity to Clausewitz. Eds. M. Formisano, H. Böhme. Berlin-New York 2011, s. 209-217.

Veyne P.: Imperium grecko-rzymskie. Tłum. P. Domański. Kęty 2008.

WOLSKI J.: Rzymska polityka na Wschodzie. Imperializm rzymski w konflikcie z imperializmem irańskim. W: Starożytny Rzym we współczesnych badaniach. Państwo, społeczeństwo, gospodarka. Liber in memoriam Lodovici Piotrowicz. Red. J. Wolski, T. Kotula, A. Kunisz. Kraków 1994, s. $81-103$.

Yavetz Z.: The Res Gestae and Augustus' Public Image. W: Caesar Augustus Seven Aspects. Eds. F. Millar, E. Segal. Oxford 1984, s. 1-36.

Zakrzewska-Dubasowa M.: Historia Armenii. Wrocław 1990.

Zanker P.: The Power of Images in the Age of Augustus. Trans. A. SAPhiro. Ann Arbor 1990.

Łukasz Jończyk

Regaining the legion's standards (insignia) lost at Carrhae as used by state propaganda during the reign of Augustus

Summary

Regaining the legion's standards (insignia) lost by Crassus as a result of his defeat at Carrhae was widely used in the Roman propaganda during the times of Augustus. The event in question had a rich religious significance in addition to its prestige. Referred to in literature as a factor contributing to the emperor's glory, as the event was also a prerequisite of and a step towards building the Roman reign without borders. After recovering the standards, the success was celebrated not only in the above-mentioned contexts, but also as a military victory that forced the Parthians into surrendering. The occasion was similarly distinguished in numismatics and iconography, and by means of them promoted the connection of the signa with Mars the Avenger, both due to the character of the god's veneration and origins thereof. Associating the recovered standards with the god could also involve the fulfilment of Caesar's obligations and one of his promises.

Key words: the ancient Rome, Crassus, Augustus, poetry, propaganda 